\title{
The Determinates of Export in Ethiopia, an Auto Regressive Distributive Lag Bound Test Approach
}

\author{
Israel Bereket \\ Department of Economics, Jinka University, Jinka, Ethiopia \\ Email address: \\ israelbereket22@gmail.com \\ To cite this article: \\ Israel Bereket. The Determinates of Export in Ethiopia, an Auto Regressive Distributive Lag Bound Test Approach. Journal of World \\ Economic Research. Vol. 9, No. 1, 2020, pp. 20-26. doi: 10.11648/j.jwer.20200901.13
}

Received: September 4, 2019; Accepted: October 24, 2019; Published: January 7, 2020

\begin{abstract}
This paper identified some of the main determinants of export in Ethiopia for the period 1977-2016 G. C. Also the paper tried to include new variable such like export diversification index and financial development as one determinant which are not considered in the most of the previous research conducted under this area, moreover the study used a bound test approach which is not used by previous research under this area. To test empirically the relationship between export performance and its major selected determinants such as: real gross domestic product, real effective exchange rate, financial development, export diversification index, terms of trade, total investment, trade openness and major trade partner GDP per capita i.e. China. The bound testing approach of co-integration and error correction model, within the Auto Regressive Distributive Lag Model frame work is developed. The estimated results show that all explanatory variables listed above significantly affect the export performance both in short run and long run except financial development and export diversification index. With sign of coefficients all determinates variable sign is consistent to economic theories. Finally the finding indicates that policy makers should give emphasis for the determinants factor of export. Also measures must be taken to reduce the constraints deterring the performance of the export sector through diversifying and promote exports by boosting domestic capital for exports, serving to transfer technology, new product for exports, making access to new and large foreign markets easily and improving technical and management skills and Lowering barriers to firm's entry and reducing international trade cost.
\end{abstract}

Keywords: Export Performance, Auto Regressive Distributive Lag Model, Export Diversification Index

\section{Introduction}

\subsection{Background of the Study}

Every society in the world strives to achieve economic development. Achieving this economic development requires economic growth, which depends on many determinant factors. There are many macroeconomic variables that contribute to economic growth, of which export is one of the very important factors. The need for export as economic growth strategy has been accepted and it is also believed that expanding export capacity of one country [3].

Developing countries largely in Asia have increased their share in global trade continuously and the largest change of global trade share is in China through export diversification [13]. On the other hand agriculture exports face severe competition from agriculture products of Europe and
America. The case of American and European farmers is completely different from that of developing country farmers because these farmers are highly subsidized by their governments [13].

Many African countries have been experiencing poor export performance. The reason for such performance is the export portfolio of these countries, which depends on particular commodities [1]. The composition of exports from sub-Saharan Africa has remained relatively constant over time, with a relatively low share of manufacturing as well as services sector exports and high shares of all other export categories (agriculture, food, fuel and ores and metals) [2].

Like other developing countries, Ethiopia relies on natural resources as the foundation of its economic development, food security and other basic necessities of its people. Smallholder agriculture is the dominant sector in Ethiopia and its share in total world exports is still very low. 
According to UNCTAD Ethiopia's exports remain concentrated in basic commodities like coffee, oil seeds and edible vegetables they accounted 26 percent, 17 percent and 17.1 percent respectively. With respect to the destination of Ethiopia's exports, 38.75 percent of Ethiopia's total merchandise export proceeds were derived from Asian markets. 58 percent of the Ethiopian exports went to European countries, about 23.87 percent of Ethiopia's total export proceeds were to African countries and the America comprised 7.8 percent of the country's total export. In addition, the report describes that in 2016 Ethiopia exported $\$ 1.71 \mathrm{~B}$, making it the 91 largest exporter in the world. During the last five years beginning from 2011 up to 2016, the exports of Ethiopia have decreased at an annualized rate of -65.861 percent, from $\$ 2.88 \mathrm{~B}$ in 2011 to $\$ 1.71 \mathrm{~B}$ in 2016 .

\subsection{Problem Statement}

Ethiopia's export sector depends on a few agricultural products mainly coffee, oilseeds and pulses. However, the markets for these products are largely unstable in terms of volume, price and carry a high degree of risk and uncertainty as well as low income elasticity. Such features are not conducive to the contribution of agricultural exports [11].

Most of the empirical studies in the area consider either the supply side or the demand side of export and also the previous study overlooked the impact of financial development \& export diversification and moreover none of the previous study conducted using Auto Regressive Distributive Lag Model to empirically estimate export determinates rather they used the traditional time series econometrics model such as Johansson co-integration and Vector Error Correction Model, Two Stage Least Square approaches, and other panel data model such as fixed effects and generalised methods of moments and Gravity model. Therefore considering this both variable and methodology as a research gap, this study set out to identify the major determinates factors that affect export performance of the country using ARDL.

\subsection{Objective of the Study}

The general objective of this study is to empirically analyze the determinants of export in Ethiopia from the period 1977 - 2016 G. C. More over the specific objective of the study was to assess the structure and compositions of total export in the Ethiopia; to identify the influence of major factors determine the total export in Ethiopia and to investigate the long term and short term effect of the determinate factors on the total export of Ethiopia.

\subsection{Research Hypothesis}

The following hypotheses are would be tested for the statistical significance or non-significance of data. There is no significant influence of major determinates factors on the total export of Ethiopia. There is no long term and short term relationship between determinate factors and total export of Ethiopia.

\section{Research Methodology}

\subsection{Research Design}

This study is conducted to identify the factor Ethiopian export. In order to address the stated objectives the study used quantitative approaches. Also the study used time series data using the longitudinal research design.

\subsection{Data Sources and Data Type}

The data used for the study is annual time series covering the period between 1977-2016 G. C. and Secondary source of data. The principal sources are from Central Statistical Agency, National Bank of Ethiopia, Ministry of Finance and Economic Development, Ethiopian Revenue and Customs Authority and various publications of IMF \& WB.

\subsection{Data Analysis}

After the data collected the data analyzed by using both descriptive and econometrics analysis. Eviews software also used for the analysis of the data because it is the most appropriate software for time series analysis in general and for ARDL model in particular than other software such as STATA and SPSS.

\subsection{Model Specification}

Many of macroeconomics time series data are exposed to the problem of non-stationary in the process of econometric analysis. Based on the availability of relevant data this study identify the main determinants of export in Ethiopia \& employ an ARDL econometric model to estimate both the long run and short run effects of these variables on export of Ethiopia. ARDL model was introduced by Pesaran [10] in order to incorporate I (0) and I (1) variables in same estimation. Several studies have used the techniques of Engle and Granger and Johansen and Juselius (1990) and Johansen, $(1991,1992)$ to identify the co-integration between macroeconomic variables. However, these techniques require that all variables in the system be stationary and with an equal order of integration.

Accordingly the regression equation is given by,

$\operatorname{LnVaExpo}_{\mathrm{t}}=\beta_{0}+\beta_{1}$ Lnrgdp $_{\mathrm{t}}+\beta_{2}$ Lnreer $_{\mathrm{t}}+\beta_{3} \operatorname{Lnfd}_{\mathrm{t}}+\beta_{4}$ Lnedvi $_{\mathrm{t}}+\beta_{5}$ Lntot $_{\mathrm{t}}+\beta_{6}$ Lninve $_{\mathrm{t}}+\beta_{7}$ Lntop $+\beta_{8}$ Lnchgpc $_{\mathrm{t}}+\mathrm{ei}$

Based on these advantages of the ARDL model, this paper employed a bound test approach. The standard ARDL model is given by the following equation.

$$
\begin{array}{r}
\Delta L n E X P O t=\beta o+\sum_{i=1}^{n 1} \beta 1 L n \Delta E X P O t_{-} i+\sum_{i=0}^{n 2} \beta 2 L n \Delta R G D P t_{-} i+\sum_{i=0}^{n 3} \beta 3 L n \Delta R E E R t_{-} i+\sum_{i=0}^{n 4} \beta 4 L n \Delta F D t_{-} i+ \\
\sum_{i=0}^{n 5} \beta 5 L n \Delta E D V I t_{-} i+\sum_{i=0}^{n 6} \beta 6 L n \Delta T O T t_{-} i+\sum_{i=0}^{n 7} \beta 7 L n \Delta I N V E t_{-} i+\sum_{i=0}^{n 8} \beta 8 L n \Delta T O P t_{-} i+\sum_{i=0}^{n 9} \beta 9 L n \Delta C H G P C t_{-} i+
\end{array}
$$




$$
\begin{aligned}
\delta 1 \mathrm{LnEXPt}_{-1}+\delta 2 \mathrm{LnRGDPt}_{-1} & +\delta 3 \mathrm{LnREERt}_{-1}+\delta 4 \mathrm{LnFDt}_{-1}+\delta 5 \mathrm{LnEDVI}+\delta 6 \mathrm{LnTOTt}_{-1}++\delta \mathrm{LLnINVEt}_{-1}+ \\
& \delta 8 \mathrm{LnTOPt}_{-1}+\delta 9 \mathrm{LnCHGPCt}_{-1}+\varepsilon \mathrm{t}
\end{aligned}
$$

The above equation also called unrestricted error additional trend included in equation (1). Hence the equation correction model (UECM).

We can have the same model described above with

$$
\begin{aligned}
& \Delta L n E X P O t=\beta o+\alpha t+\sum_{i=1}^{n 1} \beta 1 L n \Delta E X P O t_{-} i+\sum_{i=0}^{n 2} \beta 2 L n \Delta R G D P t_{-} i+\sum_{i=0}^{n 3} \beta 3 L n \Delta R E E R t_{-} i+\sum_{i=0}^{n 4} \beta 4 L n \Delta F D t_{-} i+
\end{aligned}
$$

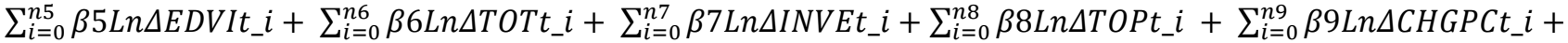

$$
\begin{aligned}
& \delta 1 \mathrm{LnEXPt}_{-1}+\delta 2 \mathrm{LnRGDPt}_{-1}+\delta 3 \mathrm{LnREERt}_{-1}+\delta 4 \mathrm{LnFDt}_{-1}+\delta 5 \mathrm{LnEDVI}_{+}+\delta 6 \mathrm{LnTOTt}_{-1}++\delta 7 \mathrm{LnINVEt}_{-1}+ \\
& \delta 8 \text { LnTOPt }_{-1}+\delta 9 \text { LnCHGPCt }_{-1}+\varepsilon \mathrm{t}
\end{aligned}
$$

The null and alternative hypotheses for co-integration test among variables in equation (1) are: $\mathrm{H} 0: \delta 1=\delta 2=\delta 3=\delta 4=$ $\delta 5=\delta 6=\delta 7=\delta 8=\delta 9=0$ (no long-run relationship).

Ha: $\delta 1 \neq \delta 2 \neq \delta 3 \neq \delta 4 \neq \delta 5 \neq \delta 6 \neq \delta 7 \neq \delta 8 \neq \delta 9=0$ (a long-run relationship).

Likewise, in order to test the existence of the short-term relationship among the identified variables in Eq. (1) we can formulate the $\mathrm{H} 1$ and $\mathrm{H} 0$ hypothesis as follows:
$\mathrm{H} 0: \beta 1=\beta 2=\beta 3=\beta 4=\beta 5=\beta 6=\beta 7=\beta 8=\beta 9=0$ (No short-run relationship).

Ha: $\beta 1 \neq \beta 2 \neq \beta 3 \neq \beta 4 \neq \beta 5 \neq \beta 6 \neq \beta 7 \neq \beta 8 \neq \beta 9 \neq 0$ (There is short-run relationship).

If there is evidence of long-run relationship (co-integration) of the variables, the following long-run model will be estimated:

$$
\begin{array}{r}
\text { LnEXPOt }_{=} \alpha 1+\sum_{i=1}^{p} \theta 1 \text { LnEXPOt }_{i}+\sum_{i=0}^{q} \theta 2 \text { LnRGDPt }_{i}+\sum_{i=0}^{r} \theta 3 \text { LnREERt }_{i}+\sum_{i=0}^{S} \theta 4 \text { LnFDt }_{i}+\sum_{i=0}^{v} \theta 5 \text { LnEDVIt }_{i}+ \\
\sum_{i=0}^{u} \theta 6 \text { LnTOTt }_{i}+\sum_{i=0}^{z} \theta 7 \text { LnINVEt }_{i}+\sum_{i=1}^{L} \theta 8 \text { LnTOPt }_{i}+\sum_{i=0}^{M} \theta 9 \text { LnCHGPCt }_{i}+\mu \mathrm{t}
\end{array}
$$

\begin{tabular}{|c|c|c|c|}
\hline $\mathbf{N}_{\mathbf{0}}$ & Variable & Measurement & Expected sign \\
\hline 1 & Total Value of Exports & Export value at time, & \\
\hline 2 & Real Gross domestic product & Value of real gross domestic product at time $t$, & $\overline{+} \mathrm{ve}$ \\
\hline 3 & Real effective exchange rate & Real effective exchange rate at time $t$, & -ve \\
\hline 4 & Financial development & A proxy for broad money $\left(M_{2}\right)$ as a ratio of GDP at time $t$, & -ve \\
\hline 5 & Export diversification index & A proxy for diversification index value at time $t$, & $+\mathrm{ve}$ \\
\hline 6 & Terms of trade & Terms of trade (export price over import price) at time $t$, & $+\mathrm{ve}$ \\
\hline 7 & Investment & The value of investment at time $t$, & $+\mathrm{ve}$ \\
\hline 8 & Trade openness & Trade to GDP ratio or $\left(\frac{\text { Trade }}{G D P}\right)$ & $+\mathrm{ve}$ \\
\hline 9 & China GDP per capita & The value of GDP per capita at time $t$, & $+\mathrm{ve}$ \\
\hline
\end{tabular}

Finally, the ARDL specification of the short-run dynamics can be derived by constructing an error correction model (ECM).

$$
\begin{aligned}
& \Delta L n E X P O t=\alpha 0+\sum_{i=1}^{p} \gamma 1 \Delta L n E X P O t_{-} i+\sum_{i=0}^{q} \gamma 2 \Delta L n R G D P t_{-} i+\sum_{i=0}^{r} \gamma 3 \Delta L n R E E R t_{-} i+\sum_{i=0}^{S} \gamma 4 \Delta L n F D t_{-} i+ \\
& \sum_{i=0}^{v} \gamma 5 \Delta \text { LnEDVIt_i }+\sum_{i=0}^{u} \gamma 6 \Delta \text { LnTOTt }_{-} i+\sum_{i=0}^{z} \gamma 7 \Delta \text { LnINVEt }_{-}+\sum_{i=0}^{L} \gamma 8 \Delta L n T O P t_{-} i+\sum_{i=0}^{M} \gamma 9 \Delta L n C H G P C t_{-} i++ \\
& \psi \mathrm{ECMt}_{-\mathrm{i}}+\varepsilon t
\end{aligned}
$$

\subsection{Variables and Expected Sign}

Table 1. Variables and expected signs.

\section{Result and Discussion}

\subsection{Descriptive Analysis}

Table 2. Descriptive statistics summary.

\begin{tabular}{llllllllll}
\hline & Export & GDP & REER & FD & EDVI & TOT & INVE & TOP & CHGPC \\
\hline Mean & 13330437 & 292682 & 155.84 & 0.14 & 0.61 & 114.48 & 95656.05 & 137.07 & 2140.12 \\
Median & 3561443 & 168582.2 & 161.16 & 0.10 & 0.54 & 111.1 & 42942.97 & 75.56 & 1389.56 \\
Maximum & 63685744 & 1577468 & 284.75 & 0.53 & 0.98 & 150.56 & 662837.3 & 564.34 & 6894.46 \\
Minimum & 279026 & 99233 & 93.57 & 0.01 & 0.34 & 90.68 & 14116 & 16.66 & 279.32 \\
Std. Dev & 21218232 & 321429.6 & 47.75 & 0.13 & 0.17 & 13.79 & 140808.7 & 153.92 & 1969.74 \\
Kurtosis & 3.78 & 10.89 & 2.78 & 3.91 & 2.51 & 3.62 & 10.99 & 3.78 & 2.85 \\
Sum & $5.33 \mathrm{E}$ & 11707279 & 6233.7 & 5.78 & 24.65 & 4579.2 & 3826242 & 5482.9 & 85604.8 \\
Sm sq. Dev & $1.76 \mathrm{E}$ & $4.03 \mathrm{E}$ & 88929.9 & 0.70 & 1.15 & 7421.4 & $7.73 \mathrm{E}$ & 924025.6 & $1.51 \mathrm{E}$ \\
Observation & 40 & 40 & 40 & 40 & 40 & 40 & 40 & 40 & 40 \\
\hline
\end{tabular}

Source: Own construction based on Eviews result. 


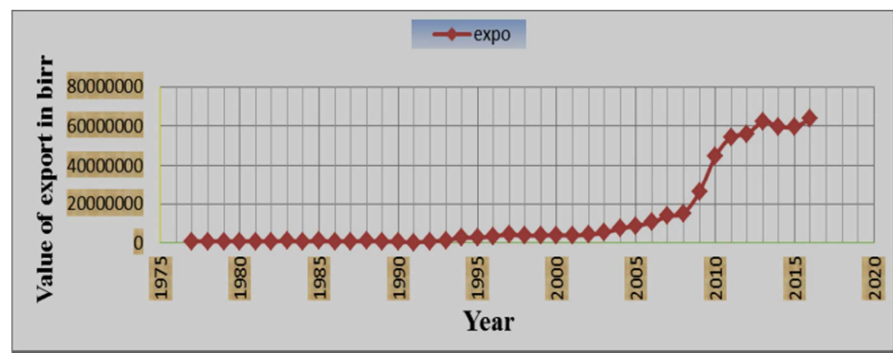

Source: Own computation based on NBE data.

Figure 1. Trend in export value.

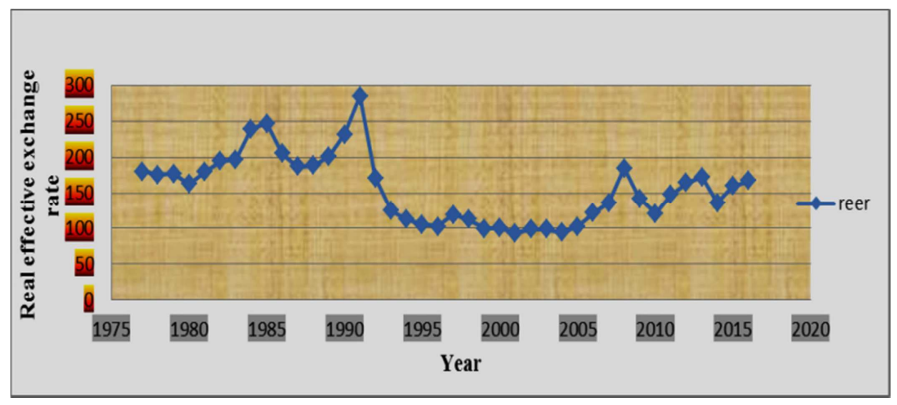

Source: Own computation based on NBE data.

Figure 2. Trend in the real effective exchange rate.

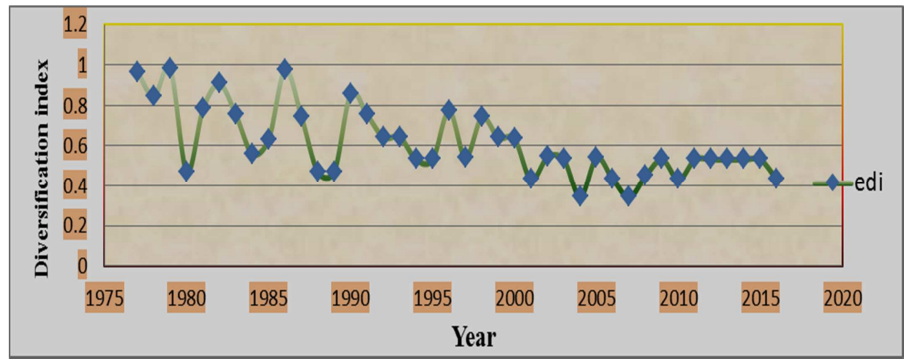

Source: Own computation based on NBE data.

Figure 3. Trend in export diversification index.

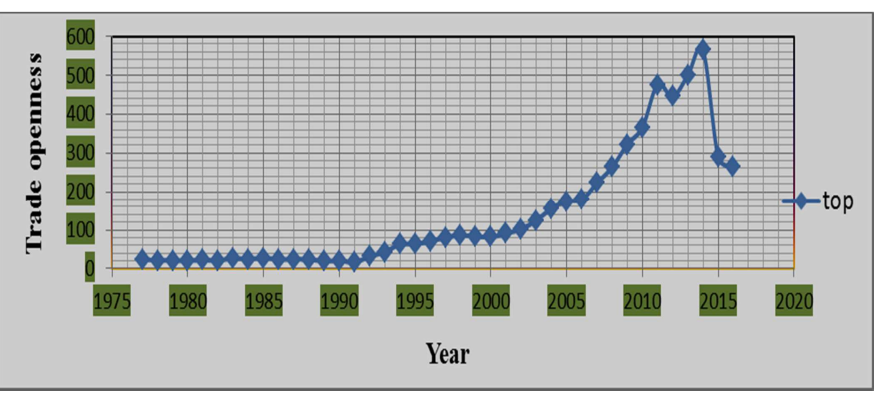

Source: Own computation based on NBE data.

Figure 4. Trend in trade openness.

\subsection{Econometrics Analysis}

\subsubsection{Unit Root Test}

Table 3. Unit root test result using the Augmented Dickey Fuller.

\begin{tabular}{|c|c|c|c|c|c|}
\hline \multirow{3}{*}{ Variables } & \multicolumn{4}{|c|}{ Test statistics under different assumption } & \multirow{3}{*}{ Stationary at } \\
\hline & \multicolumn{2}{|c|}{ Level } & \multicolumn{2}{|c|}{ First Difference } & \\
\hline & Constant & Constant \& trend & Constant & Constant \& trend & \\
\hline Lnexpo & 0.48 & -2.07 & $-5.31 * * *$ & $-5.45^{* * *}$ & I [1] at $1 \%$ \\
\hline Lnrgdp & $3.77 * * *$ & 1.04 & $-5.12 * * *$ & $-6.53 * * *$ & I [1] at $1 \%$ \\
\hline Lnreer & -1.68 & -1.59 & $-5.27 * * *$ & $-5.23 * * *$ & I [1] at $1 \%$ \\
\hline Lnfd & -0.84 & -2.59 & $-6.35 * * *$ & $-6.38 * * *$ & I [1] at $1 \%$ \\
\hline Lnedvi & $-4.06 * * *$ & $-5.87 * * *$ & $-8.06 * * *$ & $-8.02 * * *$ & $\mathrm{I}[0]$ at $1 \%$ \\
\hline Lntot & $-3.79 * * *$ & $-4.06^{* *}$ & $-8.56^{* * *}$ & $-8.47 * * *$ & I [0] at $1 \%$ \\
\hline Lninve & 1.15 & -0.76 & $-7.30 * * *$ & $-7.97 * * *$ & I [1] at $1 \%$ \\
\hline Lntop & -0.41 & -2.41 & $-5.47 * * *$ & $-5.37 * * *$ & I [1] at $1 \%$ \\
\hline Lnchgpc & -0.54 & $-3.40 *$ & $-3.88 * * *$ & $-3.63 * *$ & $\mathrm{I}[1]$ at $1 \%$ \\
\hline
\end{tabular}

ADF Test Critical Value at Level and First Difference with Constant only, :- $1 \%=-3.62$, :- 5\% $=-2.94$ and :- $10 \%=-3.20$. ADF Test Critical Value at Level and First Difference with Constant and Trend, :- $1 \%=-4.21$, :- $5 \%=-3.53$ and :- $10 \%=-3.19$.

Note: $* * *$, and $* * *$ indicates the level of significance of each variable at $10 \%, 5 \%$ and $1 \%$ respectively. To sum up the ADF test results or stationary test indicates that all variables under the study are either I (0) or I (1) and also we reject the null hypothesis of unit root problem. Moreover based on these two tests none of the variables is integrated of order two. Once the nature of the variables determined and all variables included in the model are qualifying the primary required assumption whenever using the ARDL approaches. so we can proceed with ARDL bound testing approach or we can apply ARDL (auto regressive distributed lag model) approach to the current study in order to examine the existence of long-run and short run relation between our dependent variable value of export (EXPO) and independent variables.

\subsubsection{Optimal Lag Length Selection Criteria}

Because the computation of F-Statistics for cointegration is very sensitive to lag length, in the first step we need to select a lag order on the basis of the SBC, AIC and HQ. Therefore based on the above criteria the software is selected two lag length. The best ARDL model selected based on the three criteria is $\operatorname{ARDL}(1,2,2,2,2$,
$1,2,0,2)$.

\subsubsection{Model Diagnostic Test}

1. Breusch-Godfrey Serial Correlation LM Test:

$\mathrm{H}_{01}$ : Null hypothesis: no serial correlation in the residual

$\mathrm{H}_{02}$ : Alternative: there is serial correlation in the residuals 
Obs*R-squared: 0.005792

Prob. Chi-Square (1): 0.9393

2. Heteroskedasticity Test: Breusch-Pagan-Godfrey: $\mathrm{H}_{01}$ : Null hypothesis: residuals are Homoscedastic

$\mathrm{H}_{02}$ : Alternative: residual are Heterosckedastic

Obs*R-squared: 21.19194

Prob. Chi-Square (23): 0.5694

3. Jarque Bera: Normality of the residuals:

$\mathrm{H}_{01}$ : Null hypothesis: the error are normally distributed

$\mathrm{H}_{02}$ : Alternative: residual are not normally distributed

J. B Statistics: 0.185809

Prob.: 0.911280

The above shows that the ARDL $(1,2,2,2,2,1,2,0,2)$ model passes all diagnostic tests considered in this study. In all the three tests above we fail to reject the null hypothesis or we accept the null hypothesis. In all the first two tests in the above table the corresponding probability of observed $\mathrm{R}$ squared is clearly greater than five percent $(93.93 \%$ and $56.94 \%$ respectively) implies that we accept the null hypothesis and reject the alternative one in all the three cases. Therefore, our ARDL model has no serial correlation, and heteroscedasticity problems.

\subsubsection{Model Stability Test}

In order to reduce the forecasting errors and unreliability of the model (avoiding misleading inferences), the study employed the three most commonly used stability tests the functional form test, CUSUM (cumulative sum) and CUSUM SQ (sum square) test for stability.

1. Functional Form test: Ramsey RESET Test

$\mathrm{H}_{01}$ : Null hypothesis: there is no omitted variable

$\mathrm{H}_{02}$ : Alternative: there is omitted variable t-statistics: 0.892049

Prob.: 0.3886

2. Cumulative Sum (CUSUM): STABLE

3. Cumulative Sum Square (CUSUMSQ): STABLE

\subsubsection{Result of ARDL Bound Test for Co-integration}

Now our next step would be examined if there exist the long-run relationship among the variables. The main assumption of the ARDL model is that the variables in the model are integrated to the order zero, I (0), order one I (1) or both. This lends support to the implementation of the bound testing. So that the ARDL bound test for the long run relationship have the Fstatistics value 10.07595 .

Table 4. ARDL Bound Test Result.

\begin{tabular}{llll}
\hline \multicolumn{2}{l}{ Critical Values Bound: } \\
\hline Significance & I [0] Bound & I [1] Bound & Inference \\
\hline $10 \%$ & 2.13 & 3.09 & Exist Relationship \\
$5 \%$ & 2.38 & 3.41 & Exist Relationship \\
$2.5 \%$ & 2.62 & 3.7 & Exist Relationship \\
$1 \%$ & 2.93 & 4.06 & Exist Relationship \\
\hline
\end{tabular}

Source: Own construction based on Eviews result.
As shown in table above the F statistics (10.07) is clearly greater than the upper bound critical value of Pesaran et. al (2001) 4.06 at $1 \%$ level of significance. This indicates that there is co-integration between dependent and independent variables. In other words, we reject the null hypothesis: $\delta 1=\delta 2=\delta 3=\delta 4=\delta 5=\delta 6=$ $\delta 7=\delta 8=0$ (no long-run relationship) accept the alternative Ha: $\delta 1 \neq \delta 2 \neq \delta 3 \neq \delta 4 \neq \delta 5 \neq \delta 6 \neq \delta 7 \neq \delta 8=0$ (a long-run relationship).

\subsubsection{Long Run Model}

After checking the existence of cointegration among variables, the next step is to estimate the long-run model. The empirical results of the long run model are presented in the below table.

Table 5. Estimated Long Run Model result using the ARDL Approach.

\begin{tabular}{lllll}
\hline Variable & Coefficient & $\begin{array}{l}\text { Standard } \\
\text { error }\end{array}$ & t-statistics & probability \\
\hline LNRGDP & 0.692487 & 0.316256 & 2.189641 & 0.0460 \\
LNREER & -0.952684 & 0.170899 & -5.574548 & 0.0001 \\
LNFD & 0.310692 & 0.228960 & 1.356975 & 0.1963 \\
LNEDVI & 0.062206 & 0.293140 & 0.212207 & 0.8350 \\
LNTOT & 0.930303 & 0.246696 & 3.771046 & 0.0021 \\
LNINVE & 0.565457 & 0.145960 & 3.874050 & 0.0017 \\
LNTOP & 0.688814 & 0.140475 & 4.903479 & 0.0002 \\
LNCHGPC & 3.192806 & 0.768239 & 4.156007 & 0.0010 \\
\hline
\end{tabular}

Dependent variable: LNEXPO.

Selected Model: ARDL (1, 2, 2, 2, 2, 1, 2, 0, 2).

Source: Own construction based on Eviews result.

As shown in table above, in the long run RGDP has a positive and significant impact on export. The estimated result shows that holding other variable constant, a $1 \%$ increase in RGDP will cause increase in export by $0.69 \%$ also the sign of the RGDP is as expected. The long run impact of real effective exchange rate on the export performance is found negative and statistically significant, the result goes parallel with the Marshal-Lerner condition and Mundel-Fleming model and also confirmed the findings of Nega [9] regarding of the negative relationships between real effective exchange rate and export. Export diversification found to have positive and insignificance shows that ceterius peribus, a one perecent increase in export diversification leads to a 0.62 percent increase in total export this implying that there is the more diversified economies that expect a stronger export performance and also it provides the opportunity to extend investment risk over a wider portfolio of economic sector.

Terms of trade has statistically significant on export and positive this is consisted with Kiros [8] found out that terms of trade has a significant positive relationship with export but though an increase in terms of trade marginally increase export. As far as the major external/demand side determinants are concerned, the estimation result indicates that the GDP per capita of China i.e. the major importer country from Ethiopia positively and significantly affects 
export of the country.

\subsubsection{Short Run Error Correction Model}

ECM (Error correction model) is use to estimate the short run relationship between the variables. The short run model can be estimated (ECMT-1) to capture the adjustment towards the long run and the model.

Table 6. Estimated Short Run Model result using the ARDL Approach.

\begin{tabular}{lllll}
\hline Variable & Coefficient & Std. Error & t-Statistic & Prob. \\
\hline D (LNRGDP) & 3.696779 & 0.557270 & 6.633728 & 0.0000 \\
D (LNRGDP (-1)) & -1.755252 & 0.585099 & -2.999925 & 0.0096 \\
D (LNREER) & -0.350973 & 0.150498 & -2.332085 & 0.0351 \\
D (LNREER (-1)) & 0.714108 & 0.159415 & 4.479555 & 0.0005 \\
D (LNFD) & 3.355532 & 0.571637 & 5.870037 & 0.0000 \\
D (LNFD (-1)) & -1.030653 & 0.460075 & -2.240185 & 0.0418 \\
D (LNEDVI) & 0.111974 & 0.101413 & 1.104135 & 0.2882 \\
D (LNEDVI (-1)) & -0.177089 & 0.096347 & -1.838022 & 0.0874 \\
D (LNTOT) & 0.319720 & 0.136112 & 2.348949 & 0.0340 \\
D (LNINVE) & 0.616657 & 0.193581 & 3.185525 & 0.0066 \\
D (LNINVE (-1)) & 0.398502 & 0.173824 & 2.292562 & 0.0379 \\
D (LNTOP) & 0.587711 & 0.145115 & 4.049978 & 0.0012 \\
D (LNCHGPC) & 3.982634 & 1.233787 & 3.227975 & 0.0061 \\
D (LNCHGPC (-1)) & -1.264806 & 1.313954 & -0.962595 & 0.3521 \\
C & -15.682979 & 3.757497 & -4.173784 & 0.2134 \\
ECT (-1) & -0.853222 & 0.090949 & -9.381285 & 0.0000 \\
\hline
\end{tabular}

Dependent variable: DLNEXPO.

Selected Model: ARDL (1, 2, 2, 2, 2, 1, 2, 0, 2).

Source: Own construction based on Eviews Result.

The First difference of all variables except the export diversification index and the lag of China GDP per capita are statistically significant with less than 5\% level to affect export in short run. In addition to this, the sign of the coefficient of all variable is positive except real effective exchange rate and the lag value of the four variables i.e. real gross domestic product, financial development, export diversification and China GDP per capita.

The lagged error term ECT (-1) in our result is negative and significant at $1 \%$ level of significance confirms the existence of long run association between the variables. The error correction coefficient which is also called speed of adjustment toward long run equilibrium after a short run shock is -0.853222 . This indicates that deviation from the long-run equilibrium is corrected at the speed of 85.32 percent over each year implies that there is "an over correction" toward long run equilibrium after a short run shock.

\section{Conclusion and Policy Implications}

\subsection{Conclusions}

Like many other Sub-Saharan African countries, Ethiopia has for long been dependent on primary commodities to partially meet its foreign exchange earnings. The central question investigated in this paper is whether or not export is significantly affected by the major selected explanatory variables. To address this question, time serious data ranging from the year 1977 up to 2016 G. C. was utilized.

Before applying the ARDL model, all the variables are tested for their time series properties (stationarity properties) using the ADF and PP tests. As a result export diversification index and terms of trade variables are stationary (no unit root problem) at level for both constant and trend, while export, RGDP, real effective exchange rate, financial development, investment and trade openness and China GDP per capita are stationary at first difference with constant and trend. However, RGDP in PP test is stationary at level with constant and trend others result for PP is similar with ADF test result.

Next to testing for time series property, the model diagnostic and stability test was done by testing the different testing techniques. The result revealed that no evidence of serial correlation, no functional form problem (the model is correctly specified), the residual is normally distributed, no evidence of hetroscedasticity problem and the model is stable. As we discussed above, this study applied the methodological approach called ARDL model also known as bound test approach. As the result indicted the bound test (Fstatistic) value is larger than the upper bound critical value for Pesaran et al. (2001), which indicates there is a long run relationship between export and its determinants in long run during the study period.

The empirical result showed that in the long run except the variable export diversification index and financial development, which are positive but insignificant other variables are found to have positive impact and statistically significant at $1 \%$ and $5 \%$ level of significance. More specifically to describe the effect of the positive and significant variable a one percent increase in RGDP, TOT, INVE, TOP, and CHGPC results 69.24\%, 93.03\%, 56.54\%, $68.88 \%, 319.28 \%$ increase in export respectively in the long run. 


\subsection{Policy Implications}

Based on the finding of this study, the following policy recommendations are forwarded: Firstly the positive and significant coefficients RGDP, suggests that macroeconomic policy reforms aimed at improving the growth of GDP that should enhances the total export supply of the countries to the rest of the world. Second, the significant relationship between the real effective exchange rate and export performance indicate that the government has to ensure a stable exchange rate policy in order to avoid the exchange rate risk. Third, the government should attempt to diversify and promote exports in order to fully exploit the benefits of the sector and promote economic growth. Fourth, the positive and significant relationship between trade partner GDP per capita i.e. China implies that a bilateral agreement with the trading partners has a vital role in enhancing the foreign earning potential from export sectors. In sum, the above measures must be maintain in order to reduce and eliminate the constraints deterring the performance of the export sector are somewhat general. A closer look and detailed investigation is very important for achieving economic growth.

\section{Acknowledgements}

A major research like this is never the work of anyone alone. The contributions of many different people, in their different ways, have made this possible. I would like to extend my appreciation especially to the following.

First of all, I would like to express my love and gratitude to my almighty God for the wisdom and perseverance that he has been bestowed upon me during this research, and indeed, throughout my life. Next I owe my special gratitude to my major advisor Dr. Atlaw Alemu for his valuable and constructive comments in all phases of the study. His guidance and quick response helped me in all the time of research and writing of this thesis. Also I would like to extend my heartfelt gratitude to my co-advisor Melkamu Wolde (MSC) for his guidance and suggestions.

Secondly, I want to express my thanks and respects for different institutions and organization such as National bank of Ethiopia (NBE), Central Statistics Agency (CSA) and Ministry of Finance and Economic Development (MoFED) workers for their assistance and cooperation to obtain data required for the analysis of the study.

Finally, I want to express my gratitude thanks and appreciation to my family, especially my father Bereket M. and my mother Lidiya $\mathrm{T}$. for their unreserved help, care and Encouragement throughout my study and my life as a whole, also I would like to express my thanks for my best sister Meklit Bereket, for her moral support and encouragement and to all of my friends and relatives, for their support from the beginning up to the end of the this study.

\section{References}

[1] Adebusuy, B. (2004). Stabilization of Commodity Market of Interest to Africa: Working Paper.

[2] Beshir, M. (2010). The Determinants of Export of Primary Commodities in Sub-Saharan Africa: A Panel Co-Integration Approach. MSc thesis.

[3] Denekew, A. (2016). The Determinate of Export Performance in East African Countries: A Panel Data Approach. A Master Thesis Submitted to School of Graduate Studies Addis Ababa University. Addis Ababa, Ethiopia.

[4] Granger, E. a. (1987). Co-integration and error correction: representation, estimation and testing.

[5] Johansen, S. and Juselius, K. (1990) Maximum likelihood estimation and inference on co-integration with applications to the demand for money, Oxford Bulletin of Economics and Statistics 52: 169-210.

[6] Johansen, S. (1991) Estimation and hypothesis testing of cointegration vectors in Gaussian vector autoregressive models. Econometrica 59: 1551-1580.

[7] Johansen, S. (1992) The role of the constant term in cointegration analysis of non stationary variables. Forthcoming in Econometric Reviews.

[8] Kiros, H. (2012, Ethiopia). Determinants of Export Growth Rate in Ethiopia 1980-2010: Co Integration and Error Correction Model Analysis.

[9] Nega, M. (2013). The main determinants of export performance in Ethiopia for the period 1974-2011, Addis Ababa University, Addis Ababa, Ethiopia.

[10] Pesaran et al, (2001) Bounds testing approaches to the analysis of level relationships, Journal of Applied Econometrics, 16 (2001), pp. 289-326.

[11] Tigist, Y. (2015). Impact of Agricultural Export on Economic Growth in Ethiopia: The Case of Coffee, Oilseed and Pulses. Egerton University, Department of agricultural economics and agri business managment.

[12] UNCTAD. (2016). various issue.

[13] World Bank. (2013). World Development Indicator. World Bank. 